\title{
Systematic motivation work in the language classroom - An action research study from southern Norway
}

May Olaug Horverak ${ }^{1}$, Mariette Aanensen ${ }^{2}$, Gerd Martina Langeland ${ }^{3}$, Inger Olsbu ${ }^{4}$, Thorsten Päplow ${ }^{5}$

\begin{abstract}
This study investigates whether a systematic approach to working with motivation can support students in developing a metacognitive language-learning strategy that increases intrinsic motivation to learn. To do so, we carried out an intervention where we applied a motivation model in eight language groups in various upper secondary schools. This method focused on identifying goals, success factors, and obstacles. In addition, the method encouraged the making of an action plan to increase the possibility of reaching individual goals. Our findings show that the students studying English were more concerned with mastering skills, in particular speaking, whereas the foreign language students were more concerned with performance-based objectives, such as learning grammar and getting good grades. Also, we saw that many of the English students found the approach useful and motivating, whereas most of the foreign language students were somewhat negative to it. As this study involved a limited number of groups, it could be regarded a pilot study. Despite this limitation, we conclude that the five-step motivation method presented here may provide a useful tool for developing self-regulated learners.
\end{abstract}

\section{KEYWORDS:}

motivation, language learning, self-regulated learning, self-determination theory

\footnotetext{
${ }^{1}$ Birkenes Learning Centre; may.olaug.horverak@birkenes.kommune.no

${ }^{2}$ University of Agder

${ }^{3}$ Møglestu vgs

${ }^{4}$ University of Agder

${ }^{5}$ University of Agder
} 


\section{Introduction}

Perhaps no single phenomenon reflects the positive potential of human nature as much as intrinsic motivation, the inherent tendency to seek out novelty and challenges, to extend and exercise one's capacities, to explore, and to learn.

(Ryan \& Deci, 2000, p. 70)

Motivation is a central concept in learning and education, and research shows that intrinsic motivation supports human development and learning. It is therefore unsettling that national queries disclose a lack of motivation among Norwegian students in upper secondary school (Skoleporten, 2017), as well as high drop-out rates. The causes of drop-out are complex, but there is a confirmed link between motivation and drop-out rates. A major American study holds low motivation and lack of involvement in school as the primary underlying risk factors for drop-out (Rumberger, 2011). The new limit for absences from upper secondary school introduced in Norway in 2016/2017 has led to reduced absence rates, but paradoxically, the statistics show that more students fail in different subjects (Ogre \& Gjellan, 2017). Previously, a student could receive a grade in every subject if the teacher had sufficient basis for assessment, regardless of the students' absence from classes in general. With the strict limit on absences introduced recently, it is probable that many students fail to receive a grade because they have been absent more than the allowed $10 \%$ during the year in some subjects, and it does not help that they have attended all tests and handed in all assignments. One of the consequences of this change in requirements may be that students' motivation drops even more.

To gain insight into, and help to counter, these problems, we have conducted an action-research project in the southern region of Norway, where we worked systematically with motivation in various subjects in school. The goal of the project was to make students experience increased intrinsic motivation to learn and complete upper secondary school. This general approach to working with motivation was also applied in language classes, with a focus on language learning. The current study focuses on this context, more specifically on English, German and Spanish classes in upper secondary school, and presents a pilot-study of how a universal approach to working with motivation could be adjusted to an approach to learning languages. 


\section{Nordic Journal of Modern Language Methodology}

The competence aims of both the English and the Foreign Language Subject Curriculum integrate the idea of the self-regulated learner, as students are to use different strategies to master the language and evaluate their own learning (English subject Curriculum, 2013; Subject Curriculum for Foreign Languages, 2013). There is a strong relationship between self-regulation and motivation (Boekaerts, Pintrich \& Zeidner, 2005; Zimmerman \& Schunk, 1989), something that is also emphasized in an official NOU-report on education (2014). This report states that students' metacognition and ability to self-regulate learning could have positive effects on motivation. It has been indicated that developing metacognitive skills will be emphasized even more in future curricula.

Metacognition and metacognitive skills can be defined as "how individuals construct alternative problem-solving paths, and how they specify various subgoals [...] identifying the problem, examining and comparing solutions, executing the action plan, and monitoring" (Boekaerts, Pintrich \& Zeidner, 2005, p. 440). These elements are included in the method we apply in our project, which aims to help students become self-regulated learners in a language-learning context.

The main research question for this study is: Can a systematic approach to working with motivation support students in developing a metacognitive language-learning strategy that increases intrinsic motivation to learn? To answer this question, we carried out an intervention in language classes, where we applied a learning strategy which involved planning and evaluating own learning, central elements in metacognitive learning-strategies (Cohen, 2011). In this study, we also investigate student self-reported goals, their success factors, their hindrances, as well as their action plans. Hence, we also investigate the following sub-questions in our study:

a. What are the students' goals when learning languages?

b. What success factors and obstacles do students experience?

c. What do students focus upon in their work, and how do they plan to achieve their goals? 


\section{Nordic Journal of Modern Language Methodology}

The method we applied is based on a pilot-study carried out in the subject Norwegian, where the students reported that this was a very useful approach (Langeland, Horverak \& Fagerhaug, 2018). In this study, the method was adjusted to the language-learning classroom.

\section{English and foreign languages in a Norwegian context}

In Norway, English has a different status than other foreign languages, and it has been considered a second language in Norwegian school curricula since 2006. Even though English is defined a second language in the curricula, one could argue that it has a status in between a foreign and a second language, as it is not an official language in Norway (Graddol, 2006; Rindal, 2012). There is, however, an increased use of English in various official contexts, for example in education, in business and in governance (Hellekjær 2007, 2010). Whether or not we define English as a second language, English is the lingua franca of the world, including Norway, and this makes the status of English different from the status of other foreign languages.

Norwegian pupils learn English from their first year in primary school and through the first year of upper secondary school if they choose general studies. The curriculum for the obligatory English in upper secondary school is spread over two years in vocational studies programmes, where foreign languages are not obligatory. Only pupils who choose general studies have to study a foreign language.

The most common foreign languages taught in Norwegian schools are German, Spanish and French. Pupils can choose to start with a foreign language their eighth year in school and continue for five years until the end of the second year of upper secondary school, or they can start with a foreign language their first year of general studies in upper secondary school and continue until the end of the third year. As pointed out in Carrai's research on motivation in foreign languages in Norway, many pupils drop out of foreign language classes during the three years in lower secondary school (Carrai, 2014), something that indicates a lack of motivation in foreign language learning.

\section{Intrinsic motivation}

According to Ryan and Deci's Self Determination Theory (SDT), optimal learning outcomes are created if students experience intrinsic motivation (2000). Intrinsic motivation is defined 
as behaviours that are "performed out of interest and for which the primary 'reward' is the spontaneous feelings of effectance and enjoyment" (Ryan \& Deci, 2017, p. 14). Extrinsic motivation, on the other hand, is defined as behaviours that are "instrumental for some separable consequence such as an external reward or social approval, avoidance of punishment, or the attainment of a valued outcome" (Ryan \& Deci, 2017, p. 14). While behaviours that are intrinsically motivated are in their nature autonomous, behaviours that are extrinsically motivated can be either controlled or autonomous. More autonomous behaviours give access to more organismic support for acting, and this explains the affective and cognitive advantages of autonomous behaviours, whether these are intrinsically or extrinsically motivated (Ryan \& Deci, 2017, p. 15). Research shows that students with higher motivation pay more attention to their own learning process and progress more rapidly than unmotivated students (Schunk \& Zimmerman, 2012, p. 2).

Ryan and Deci list three innate psychological needs that when met serve to foster motivation and well-being, namely competence, relatedness and autonomy (2000). This means that learners need to experience mastery during the learning process, that they need to interact with others and that they need to be agents of their own lives to experience intrinsic motivation. To enhance intrinsic motivation, it is important that students are self-regulated learners that generate thoughts, feelings and actions toward attainment of goals in a social context (Boekaerts, Pintrich \& Zeidner, 2005; Zimmerman \& Schunk, 1989).

Studies on motivation in Nordic countries emphasise the importance of students feeling competent and experiencing mastery in foreign language classes (Carrai, 2014, Cardelús, 2015). Among other things, these studies argue that it is a key element for learners to feel satisfied and intrinsically motivated. Several research studies show that intrinsic motivation helps students be more persistent in their learning (Deci \& Ryan, 1985; Ushioda, 2008; Sansone \& Harackiewicz, 2000; Stipek, 2006). Carrai also emphasises the role of the teacher and the importance of creating a social context where social and emotional needs are met in an environment that prevents them from feeling "language anxiety" (2014).

Studies have also found that teachers who are "autonomy supportive" provide helpful conditions for students' intrinsic motivation, curiosity and desire for challenge in addition to learning outcomes (Deci, Nezlek, Sheinman, \& Manis, 1981; Flink, Boggiano, Barrett, \& Sherman, 1990; Reeve \& Jang, 2006; Ryan \& Deci, 2000; Ryan, Grolnick, \& Sarason, 1986). 


\section{Nordic Journal of Modern Language Methodology}

Lamb's review of research on the motivational effects on language teaching also finds that learners' motivation is influenced by the feeling of control of their own learning process (Lamb, 2017). The results reveal the importance of creating an environment that fosters students' self-motivation and autonomy (Lamb, 2017; Reeve, Deci \& Ryand, 2004). In addition, Lamb refers to Dörnyei’s taxonomy (2001) in which the promotion of learner selfconfidence seems to be valued universally by both teachers and learners (Lamb, 2017). Lamb's review also reports on studies that deal with the principle of "relatedness" in selfdetermination theory (Dörnyei, 2007; Chang, 2010; Koga, 2010), and findings from these studies show that positive relationships in a class can promote motivation. The current study focuses on developing a method that can meet all the three human needs presented in selfdetermination theory, i. e. autonomy, competence and relatedness. The purpose of the method developed in the current study is to support students in becoming intrinsically motivated and self-regulated learners in a safe psychosocial learning environment.

\section{Methodology}

We define our project as action research (Postholm, 2007) as we have carried out an intervention based on a perceived need for increased motivation to learn in upper secondary schools in Norway. The aim of the project is to investigate whether a systematic approach to working with motivation can support students in developing a metacognitive learning strategy for learning languages that increases intrinsic motivation. In the following, we describe the research design, the intervention, the kinds of data collected, and the method of analysis. In the final section, we discuss the limitations of the study.

\section{Research design and intervention}

The intervention in this project included three main sessions. The teachers carried out one session each week. After the intervention, both students and teachers filled in questionnaires with open questions.

The intervention was partly conducted in the target language and partly in Norwegian, and included what we call a five-step motivation method. In this method, students reflect on 5 central elements for achieving motivation; goals, success factors, obstacles, focus area and actions. In the intervention described here, the five questions were split in 2 sessions, and the 
third session repeated the two final questions. In addition, the students assessed how they managed to follow their own plan in the third session. Figure 1 illustrates the process of how the five-step approach was implemented.The three sessions of the intervention can be illustrated like this:
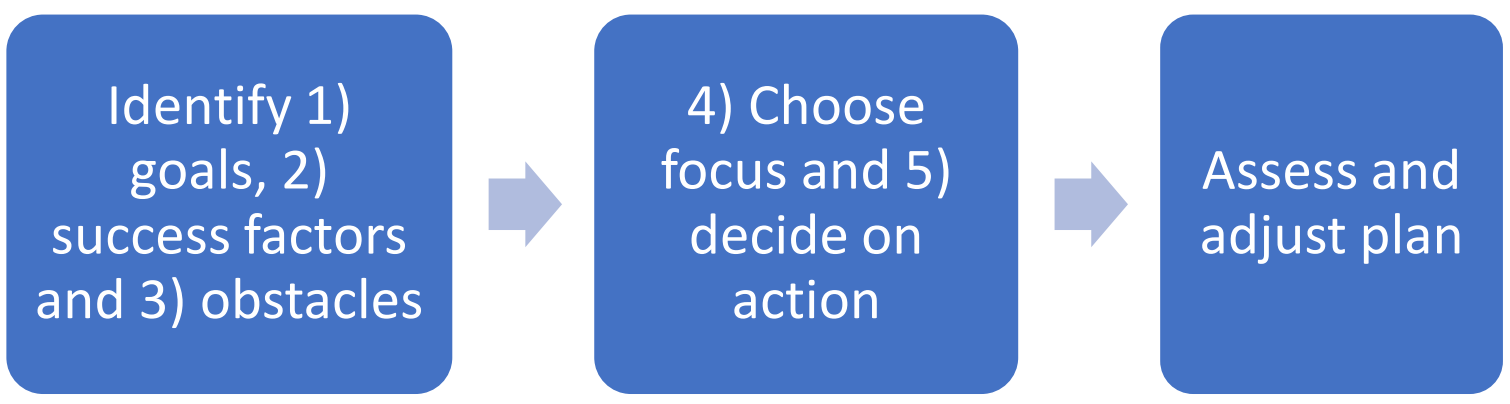

Figure 1: The implementation of the five-step motivation method

In the first session of the intervention, the teachers discussed the following questions: How do you feel about this subject now? What do you find easy and what can be a challenge?

Following this discussion, the teachers handed out papers with empty boxes for the students to fill in anonymously, and where they were to answer the following questions: 1) What do you want to accomplish in English/Spanish/German? What is your goal? 2) What is it about yourself and your actions that help you accomplish your language goals? 3) Is there something about you or your everyday life that prevents you from reaching your goal? The students were also told to invent a number that they could remember and use this on all handins throughout the project, so that it was possible to return the papers to them if needed and identify the progression of individuals in the material. The teacher collected the students' anonymous reflections.

The second session started with the teacher summing up the students' answers from the first session. Then the class discussed what types of measures could be taken to reach the different goals and to overcome the obstacles that were reported. The teacher also showed a short videoclip to the students presenting a focus model emphasising the need to sort what is important and what is urgent and how to plan what to focus on to reach the set goals. Following this, the students were given a paper with an empty action plan to fill in, and they were to answer the following questions: 4) What do you plan to work with in order to achieve 


\section{Nordic Journal of Modern Language Methodology}

your goals in this subject? 5) What specifically will you do to achieve these goals? The teacher collected the students' action plans.

In the third session of the intervention, the students assessed whether they were heading in the right direction in relation to the plan, and whether there was something they needed to adjust. The teacher collected the assessments and adjusted plans. In some of the participating groups, this intervention was repeated two times, one time in the first semester, and one time in the second semester. Some of the groups joined the project in the second semester, and the intervention was only carried out once.

The five-step motivation method as described here is designed to meet the three basic needs for competence, autonomy and relatedness. By taking control of their own learning process, deciding on what goals to work with and what to do to reach the aims, the students may feel autonomous in the learning process. When the students decide their own aims, it may be easier for them to choose an attainable end, so they will experience competence. The discussions in class may provide the students a feeling of relatedness. In order to investigate how the five-step approach worked in a language-learning context, and how it affected the students, we have chosen a mixed methods approach to investigate the students' own reflections, combining qualitative and quantitative data.

\section{Data collection and analysis}

The material containing the students' reflections collected during the intervention in the second term is included in the data material in this study. This material includes reflections concerning goals, success factors, hindrances, their work plans and evaluations of these. A thematic analysis of the material was carried out, using the qualitative analysis programme Nvivo, and we looked at tendencies in the students' reflections, converting the qualitative data into quantitative data. Hence, the main findings are presented as quantitative data. The results are partly presented through bar charts and partly through summaries and examples of individual students' reflections. As most students misunderstood question 2 about success factors, this category has not been presented in charts. The results for the English classes are presented separately, as English has a somewhat different status in Norway compared with other foreign languages as German and Spanish. 


\section{Nordic Journal of Modern Language Methodology}

The open questionnaire the students were to fill in after the intervention included the following questions: 1) Do you think the motivation sessions have been useful? Why/why not? 2) What do you think about the frequency of the motivation sessions; was there appropriate time between them? Too many? Too few? 3) In what way have the motivation sessions influenced your way of thinking, your actions, your results in the subject, and your feeling of mastery? 4) What was difficult about following your own action plan? 5) Has this work lead to an increased interest in learning in the subject? In what way? 6) Is there something that is not asked about here, something you are thinking about or want to say, that you have experienced throughout the motivation sessions? The answers to these questions are summed up in the result part and partly presented in a table.

The questionnaire that the teachers answered included questions about how they experienced the motivation method, how the students responded, and whether they had suggestions to adjusting the method. Central elements in their answers are presented in the result part.

\section{Sample}

The intervention was carried out in four upper secondary schools in the region. Table 1 below shows the distribution of teachers and students that were included in the project in the different schools. 
Nordic Journal of Modern Language Methodology

Table 1. Participants in the motivation project in English, German and Spanish classes

\begin{tabular}{llcccc}
\hline Language & Group & Teacher & School & $\begin{array}{c}\text { Participating } \\
\text { students }\end{array}$ & $\begin{array}{c}\text { Total number of } \\
\text { students in groups }\end{array}$ \\
\hline English & 1 HO & Teacher 1 & School 1 & 9 & 12 \\
English & 2 MF & Teacher 2 & School 1 & 8 & 9 \\
English & 1ST & Teacher 3 & School 2 & 23 & 28 \\
English & 1 BA & Teacher 3 & School 2 & 13 & 13 \\
English & 1NA & Teacher 4 & School 3 & 8 & 12 \\
German (2) & 2ST & Teacher 5 & School 4 & 17 & 20 \\
Spanish (1) & 2ST & Teacher 6 & School 1 & 16 & 19 \\
Spanish (2) & 1ST & Teacher 6 & School 1 & 4 & 5 \\
\hline \multicolumn{2}{l}{ Total number of students } & & $\mathbf{9 8}$ & $\mathbf{1 1 8}$ \\
\hline
\end{tabular}

Note. $\mathrm{HO}=$ Health care studies, $\mathrm{MF}=$ Restaurant and food studies, $\mathrm{ST}=$ General studies, $\mathrm{BA}=$ Building and construction studies, NA = Agricultural studies, German/Spanish (2) = German/Spanish on level 2, meaning that the students started with German/Spanish in $8^{\text {th }}$ grade. Spanish (1) = Spanish on level 1, meaning that the students started with Spanish in year 1, upper secondary school.

In English, 5 groups participated, of which 4 were vocational studies groups and 1 was a general studies group. The total number of participants in the English groups was 61. In German, 1 group participated, and in Spanish, there were 2 groups. In total, 6 teachers participated. The total number of participants in the foreign language groups (Spanish and German) was 37. In total, there were 98 student participants. The numbers here are based on how many answered the final questionnaire. All groups are mixed-ability groups, but some of the vocational groups had many students who struggled with English.

\section{Reliability and validity}

It is a challenge to ensure reliability and validity in educational research - whether we measure what we claim to measure, if there is a causal relation between the intervention and the result, whether the findings are generalisable and whether we can trust the findings (Jacobsen, 2005). In this study, we want to find out whether a systematic approach to working with motivation can support students to develop a metacognitive learning strategy for language learning that increases intrinsic motivation to learn. To do so, we analyse qualitative 


\section{Nordic Journal of Modern Language Methodology}

data from an intervention and students' reflections on how this intervention worked. We have a limited sample, especially when it comes to the foreign languages Spanish and German, but despite this, the results suggest some interesting findings when compared with the findings from the English groups.

It is difficult to know whether students' responses are honest, and whether they have understood the questions correctly; i.e. whether their answers are reliable. It is also difficult to know whether their answers are influenced by other things that have happened during the time the intervention proceeded. The fact that we called the sessions "motivation sessions" may also have influenced the students' responses in the evaluations and made them write what they think we wanted them to write. To meet these challenges, we have chosen to combine data from the actual intervention and from students' evaluation of the motivation method after the intervention had been completed. We analyse the reflections students had during the intervention to get a better impression of how the method worked, such as what students identified as obstacles and what they chose to focus on, in addition to looking at the students' answers on the final questionnaire.

\section{Results}

This study investigates how teachers can support students in developing a metacognitive strategy for learning languages that increases intrinsic motivation to learn. In the results, we first present how the students reflected on their own progress in English, and then we present the findings for foreign languages, here meaning German and Spanish. This illustrates how the students developed a metacognitive strategy for learning, by reflecting on their own goals, success factors and objectives, and by deciding on what to focus on and how to achieve their goals.

\section{Results in English classes}

As illustrated in figure 2 below, the initial question "What do you want to succeed with in English?" showed that most of the students are preoccupied with oral language production, and only 6 replies focus on comprehension. 


\section{Nordic Journal of Modern Language Methodology}

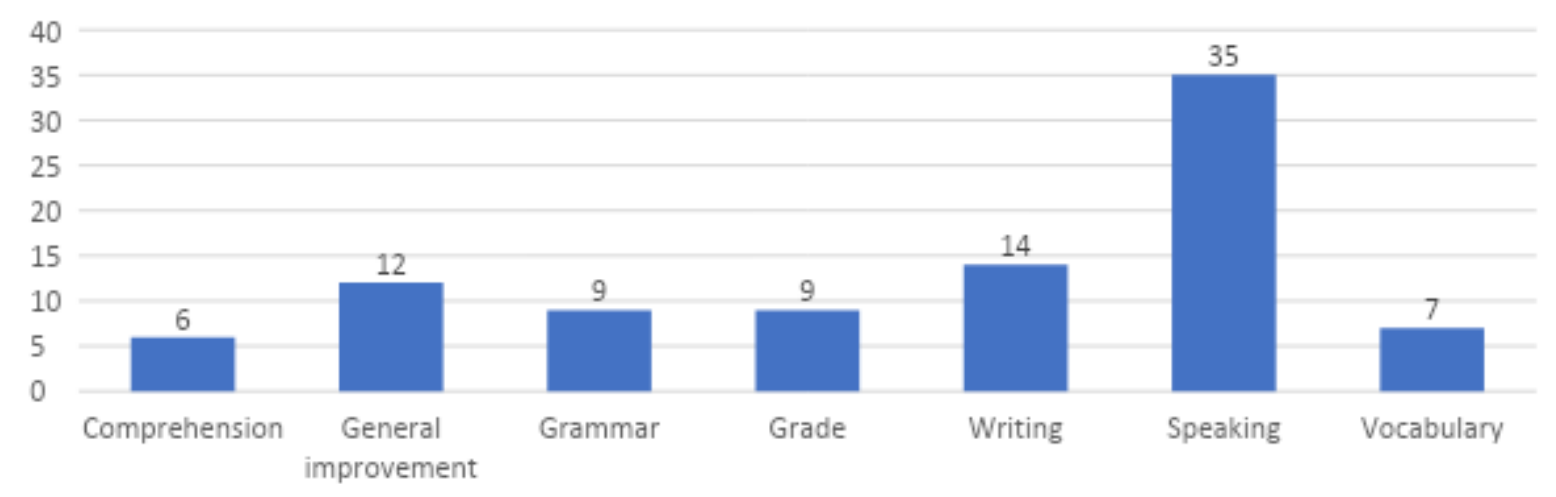

Figure 2: Goals.

About half of the students, 35 of 61, chose speaking skills as one of their focus areas. Many replies focused on being able to speak without feeling nervous: "My goal is to speak with English-speaking people and not get nervous", "I would like to be able to speak in front of the class without feeling nervous". When asked about success factors, 27 of the students focused on leisure activities such as watching streamed video-content, gaming and listening to music, 32 focused on practicing basic skills such as reading, writing and speaking, and 18 of the references were related to effort.

The obstacles mentioned by the students are illustrated in figure 3 below.

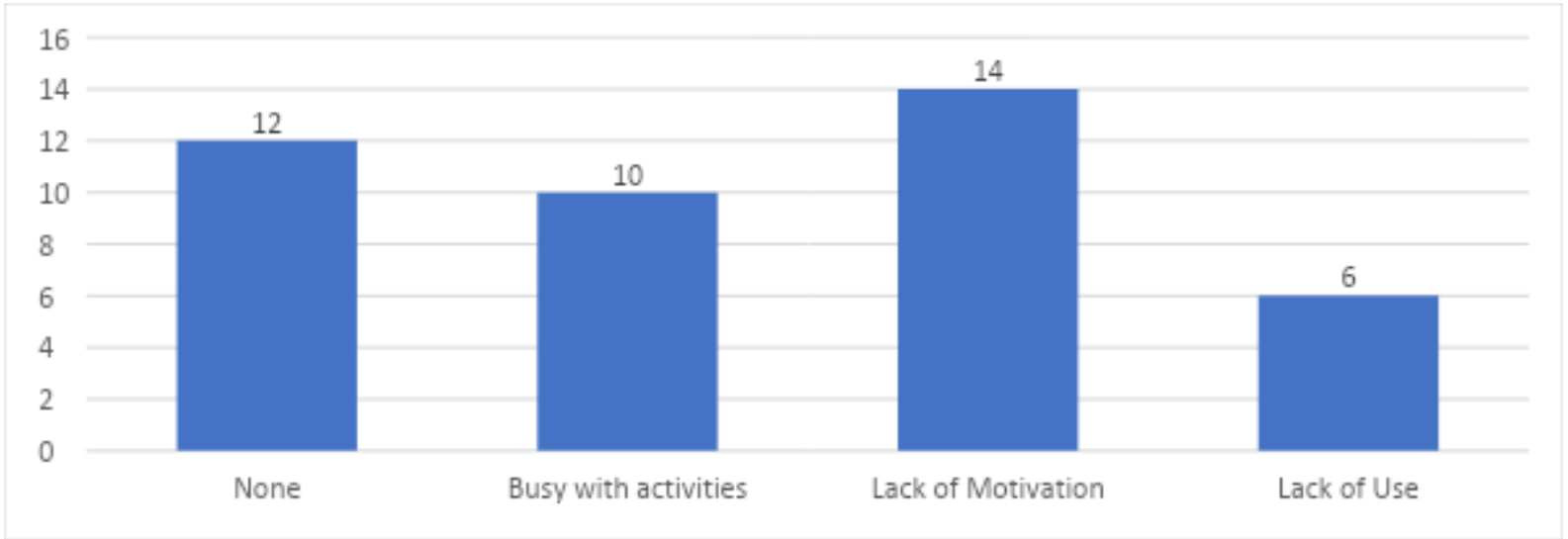

Figure 3: Obstacles 


\section{Nordic Journal of Modern Language Methodology}

Ten students mentioned after school activities as an obstacle, while lack of use of English is mentioned by 6 . Fourteen students reported lack of motivation or low self-esteem, while 12 students said that there were no obstacles.

In the second week the students created an action plan. The focus areas they chose are illustrated in figure 4 below.

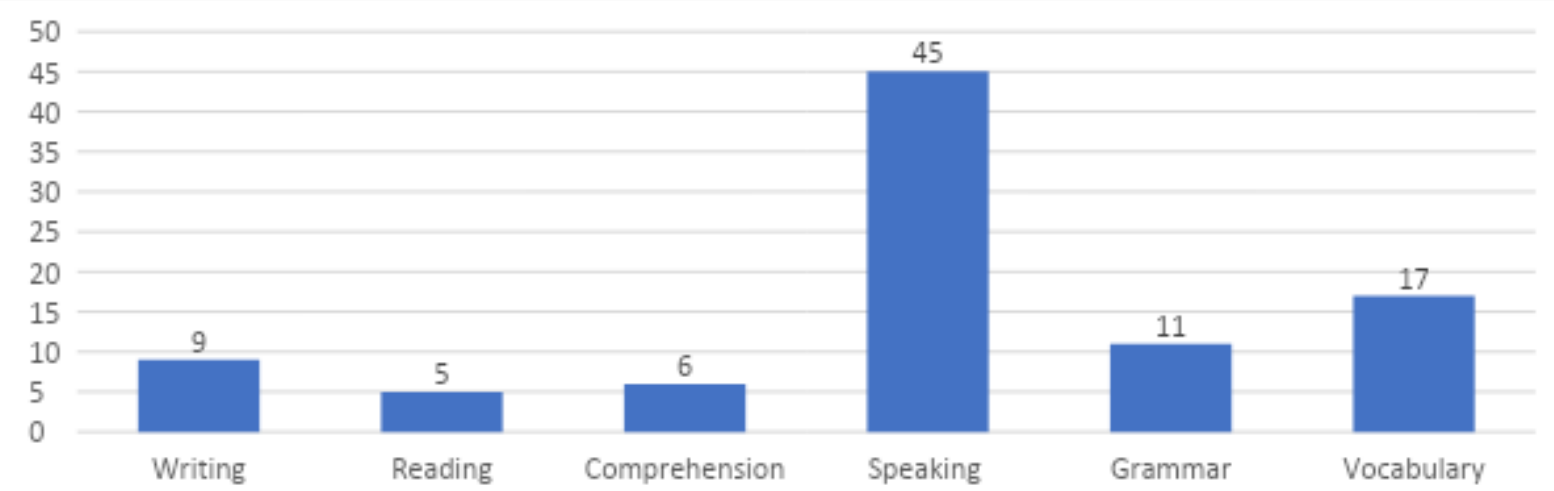

Figure 4: Focus

A majority of the students, 45 of 61 , wanted to focus on their speaking skills. Also vocabulary work was quite frequently mentioned, as 17 students wanted to focus on this. Eleven wanted to work on grammar and 9 students chose writing skills as their focus area. When asked about how to work on their focus area, the students replied as illustrated in figure 5 below.

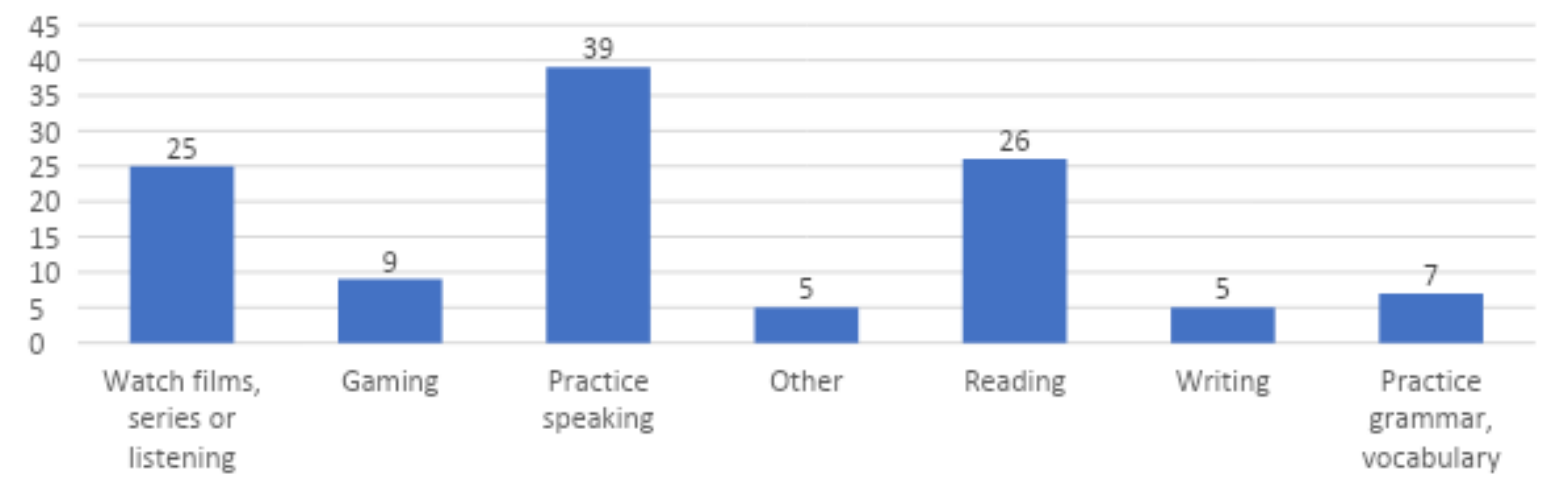

Figure 5: Action 


\section{Nordic Journal of Modern Language Methodology}

Many of the students who wanted to focus on speaking also wrote that they wanted to practice speaking, and many chose to do this in combination with other activities. A substantial number also chose watching films, reading or gaming as part of their action plans. One student replied that he or she wanted to "read more. One hour netflix per day. Speak more, play Fortnite squad one hour a week". Other students chose speaking to themselves or others for a certain amount of time. The students were asked to review their plan one week later, and at this point, 31 students reported that they were following their plan, 15 did not and 12 did to a certain extent.

When the students were asked about what they thought of the applied approach, they answered as presented in table 2 below.

Table 2. Students' answers on open questionnaire, $N=61$

\begin{tabular}{lccc}
\hline Question & Positive & Negative & Uncertain \\
\hline Useful & 29 & 27 & 4 \\
Influenced manner of thought & 23 & 29 & 3 \\
Increased motivation for learning & 18 & 39 & 2 \\
\hline
\end{tabular}

Note. Blank answers are not included, so the numbers do not add up to 61.

About half of the students found that the lessons were useful. One student responded "yes, you notice what you need to work on ", and another wrote that "they were useful because I worked on goals that I made for myself". About one third of the students reported that the lessons had influenced their manner of thought. Eighteen reported increased motivation for learning. 39 said that they were not more motivated than before the intervention, but a couple of these replied that "I already want to succeed".

\section{Results in foreign language classes}

As illustrated in figure 6 below, the students' replies to the initial question in Spanish and German were somewhat different than in English. 


\section{Nordic Journal of Modern Language Methodology}

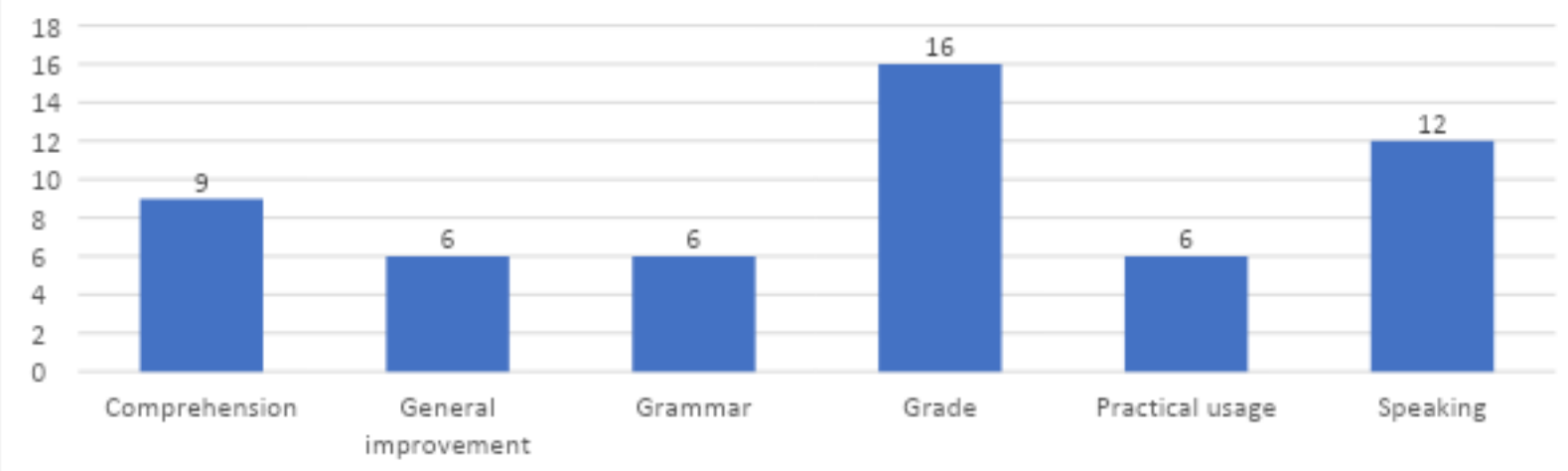

Figure 6: Goals

Sixteen students wanted to focus on getting a good grade or passing the subject. One student wrote "my aim is to pass in Spanish and to get an average grade. I also want to understand more grammar". Twelve wanted to improve their speaking skills, and some mentioned a combination of speaking and writing in being able to use the language in a practical context. Nine wanted to focus on comprehension, while 6 mentioned general improvement and 6 mentioned grammar. In terms of success factors, 12 students highlighted pre-existing skills as important, 8 reported their ability to study for tests and 9 wrote that their effort in the subject was most important. Many students reported the following: "I am determined to work hard to prepare for tests".

The obstacles mentioned by the students are illustrated in figure 7 below.

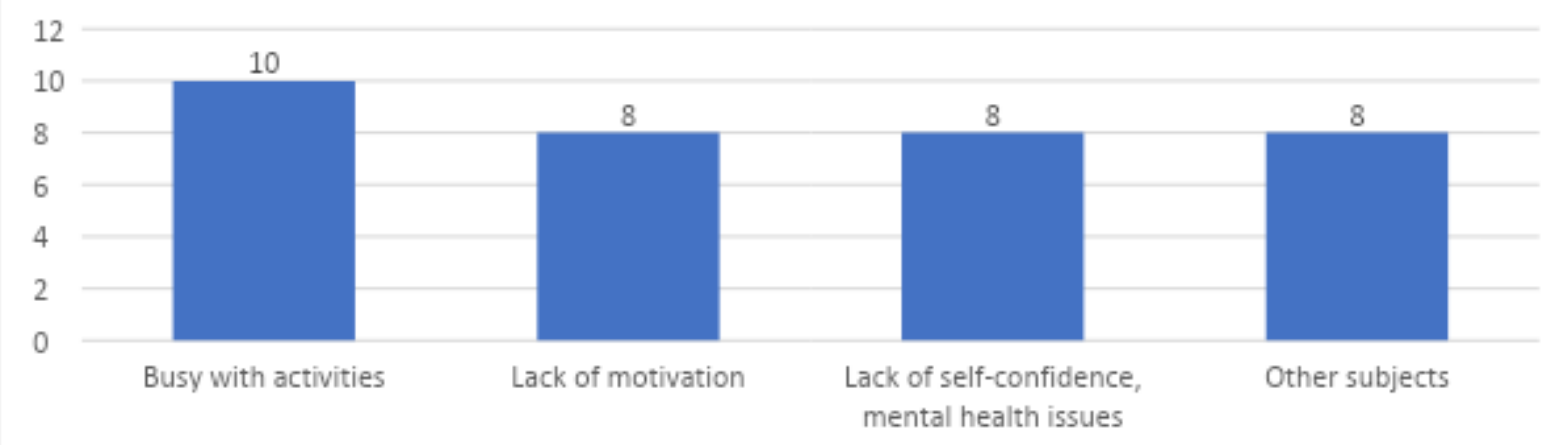

Figure 7: Obstacles 


\section{Nordic Journal of Modern Language Methodology}

Ten students mentioned after school activities as an obstacle, while other school subjects were viewed as an obstacle by 8 students. Eight students reported lack of motivation, and 8 mentioned low self-esteem or other mental health issues. One student reported, "I do not have any time, there is too much going on and that hinders me in reaching my goal. Sometimes we have three tests in one week in addition to homework and other activities and I am too tired".

In the second week the students created an action plan. Their focus areas are illustrated in figure 8 below.

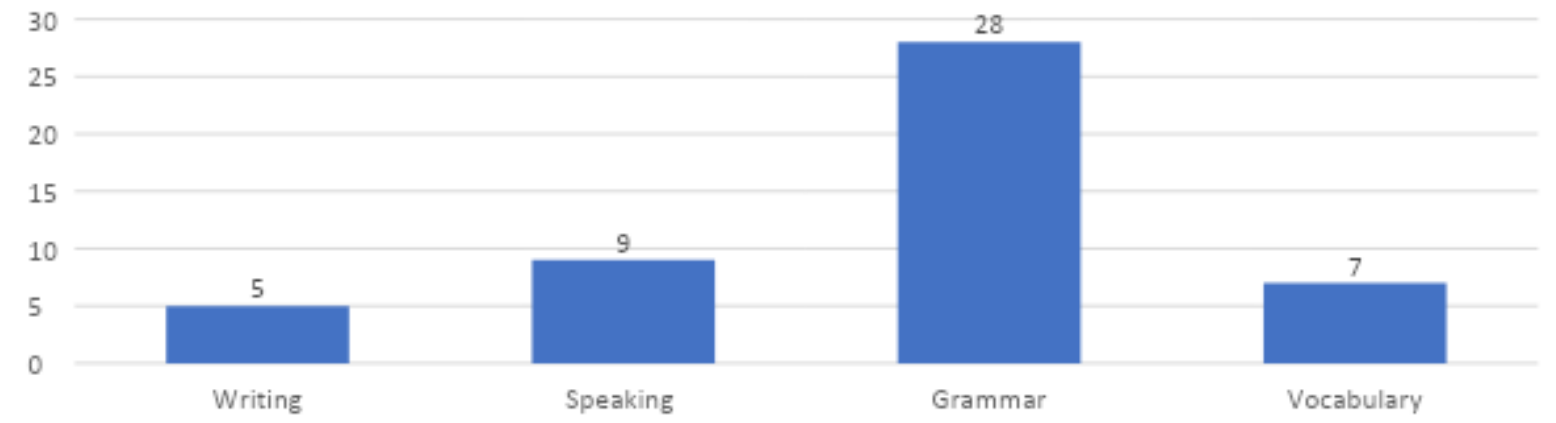

Figure 8: Focus

Most of the students wanted to focus on grammar, some were specific and wanted to work on verbs, while others just mentioned grammar in general. Some also wanted to work on speaking skills or their vocabulary. Five students wanted to improve their writing skills. The students had to write action plans for how to work on their focus area. The students' replies are illustrated in figure 9 below.

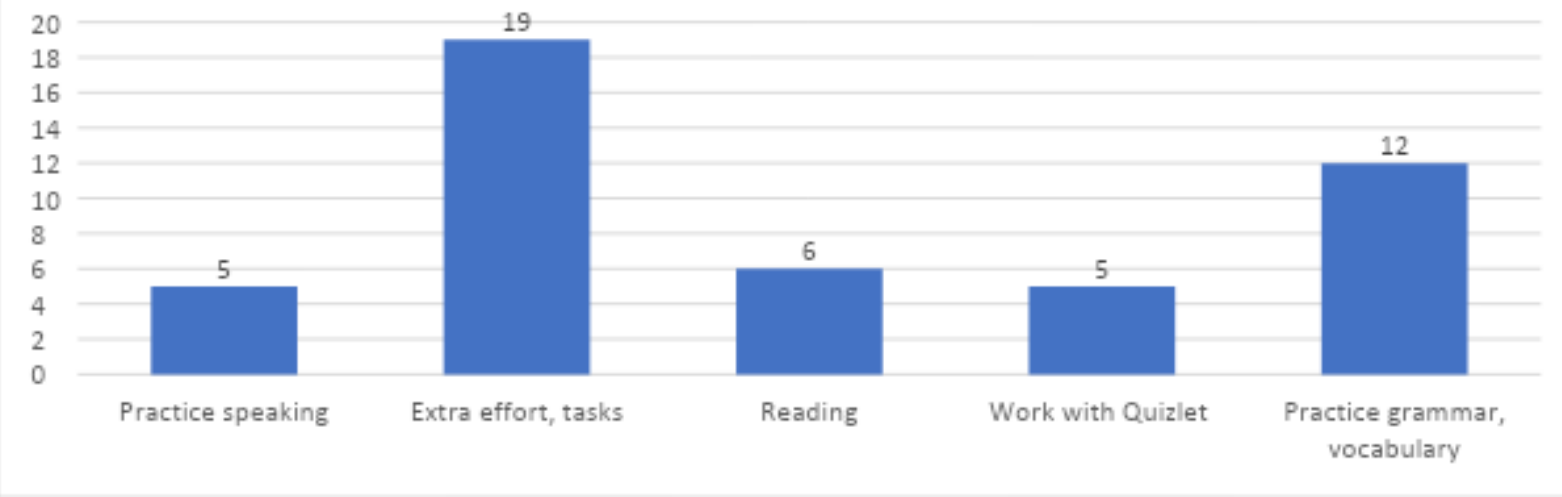

Figure 9: Action 


\section{Nordic Journal of Modern Language Methodology}

About half of the students chose extra effort in class or doing additional tasks when they wrote what they were going to do to achieve their goals. Twelve wanted to practice and study grammar and vocabulary. Five students mentioned using Quizlet as their action plan, a tool often used to work with vocabulary in foreign languages. Six chose reading and 5 wanted to practice speaking. The students were asked to review their plan one week later, and at this point, 13 students reported that they were following their plan, 12 did not and 10 did to a certain extent. Out of these, 18 reported that they just needed to follow the plan to succeed with their goals.

When asked about how they perceived the approach applied and the effect of it, the students answered as presented in table 3 below:

Table 3. Students' answers on open questionnaire, $N=37$

\begin{tabular}{lccc}
\hline Question & Positive & Negative & Uncertain \\
\hline Useful & 16 & 20 & 1 \\
Influenced manner of thought & 11 & 23 & 2 \\
Increased motivation for learning & 8 & 28 & 1 \\
\hline
\end{tabular}

About a third of the students found that the lessons were useful, while under one third felt it had influenced their manner of thought. Eight students said that they experienced increased motivation, and as in English, some expressed that they were motivated before they started. One student replied that the project had been useful as "the lessons helped me to see what I need to improve in and why I want to accomplish this", while also reporting that "it has not increased my interest".

\section{Teachers' reflections on the approach}

It made me conscious of how important it is that students themselves reflect on their own English skills and what they want to work with, instead of the teacher telling them what to focus on. - Teacher quote 


\section{Nordic Journal of Modern Language Methodology}

The teachers had different experiences with applying the motivation method in the language classroom. Some teachers reported that the students seemed to find this motivation work useful, other teachers experienced that the students became more demotivated by using this method. One of the positive aspects emphasised by the teachers was that the students were required to choose their improvement areas themselves, as we see in the quotation above. Generally, the teachers found it positive that the students had to reflect on the fact that they must take responsibility for their own learning, and to make plans for how to reach their personal goals and overcome obstacles. One teacher also said: "It was positive to go through the students' challenges in class, and the ways we could 'attack' these challenges". Another aspect that was mentioned was that it is positive that the students wrote down what hindered them in learning in general, and that this does not have to be subject-related but could be something in the students' private lives.

One of the problematic aspects with the intervention that was mentioned was that the students had to fill in many forms, and this is mentioned as a possible cause of the negative attitudes expressed by quite a few students. Another challenge was that the students struggled with using the target language while working with this approach, as they lacked words to express their goals and challenges and had problems understanding the videos that were played in class. At the same time, some of the teachers reflected that using the target language while working with this method could be useful if the students are provided with vocabulary they need, for example vocabulary to express own opinions and feelings, and if they practice the type of sentence structures they may need, for example structures with auxiliary verbs.

Most teachers reported that the frequency of the motivation sessions could have been adjusted. For example, there could have been more time from the second session, when they made the plan, to the third session, when they assessed it. It was also suggested that the students should work this way from the beginning of the school year and throughout the year. Another teacher suggested that this was a strategy that could be applied before they had tests, that the students were to choose one thing to focus on. In general, the teachers were positive to the method, but felt that it needed some adjustment, especially in regards of the time aspect. 


\section{Discussion}

This study investigates how teachers can support students in developing a metacognitive learning strategy for learning languages that also increases intrinsic motivation. The results show that the English students were more positive about this approach than the foreign language students were. Perhaps this is related to the fact that they are generally much exposed to English through media (Rindal, 2012), so they are more motivated to begin with in English as it is more familiar to them. In both groups, quite a few students found the method useful, while fewer of them felt more motivated to learn. Perhaps the process of setting goals and making action plans should have been repeated more often to affect the students' motivation, as pointed out by the teachers that participated.

Even if we adjust the method, it is unlikely that all students will perceive assignments and activities in all subjects to have a value as most subjects are obligatory and perhaps not of interest to the students. If the students only study languages in upper secondary school to get their final diploma so they can continue their studies, it is perhaps impossible to make them feel intrinsically motivated to learn the languages they study. If this is the case, an alternative aim is proposed by Skaalvik \& Skaalvik (2017), namely that the students develop autonomous extrinsic motivation. This means that they internalise the value of the learning activities, and that they therefore may initiate relevant learning activities with great enthusiasm, similarly to what they would do if they were intrinsically motivated (Deci \& Ryan, 2000). Even though many of the students did not experience increased intrinsic motivation, they were trained in applying a learning strategy that helps them become self-regulated learners by identifying goals, obstacles, making action plans and monitor these (Boekaerts, Pintrich \& Zeidner, 2005), and this may have supported them in developing autonomous extrinsic motivation.

If we compare the reflections on goals and focus areas in the English classes and the foreign language classes, we see that in English, students focus on becoming better at speaking, while in foreign language classes, the students seem more interested in getting good grades and learning grammar. The goals that dominate in English are examples of mastery goals, which are oriented toward developing new skills and competence and achieving a sense of mastery; the focus here is on the intrinsic value of learning (Ames, 1992). In contrast to this, the goals that dominate in foreign language classes seem to be performance goals, with a 


\section{Nordic Journal of Modern Language Methodology}

focus on learning what is necessary to achieve success that is normatively defined; the focus here is on the extrinsic value of learning.

To get good grades, the majority of the foreign language students consider it important to focus on grammar. This finding is interesting, since these students seem to place control of grammar at the core of foreign language learning. It is stated in the curriculum that students are to master language patterns, but there is more focus on language in use. More investigation and a larger sample of students would be needed to investigate whether these students' view represent a general approach to foreign language learning, and to explore possible reasons behind.

Perhaps the difference in goals is related to the status of English in Norway. Because of the dominance of English in Norwegian society, the students feel perhaps incompetent if they do not know how to speak the language. Learning to speak English is an integrative goal, as it makes it possible to become integrated in a global language culture (Kormos \& Csizér, 2014). Foreign languages, on the other hand, are perhaps not so much used outside the classroom by the students. Hence, the students are more concerned about what counts in the educational system, and they set instrumental goals. Grammar seems to dominate in foreign language teaching compared with English teaching (Askland, 2018), and perhaps this is why students feel they need to focus on this. It seems like extrinsic motivation dominates in the foreign language classroom, where students are concerned with getting good grades and improve in areas teachers prioritise, while in the English classroom, it seems like intrinsic motivation is more dominant. The students expressed a need to learn how to speak English without feeling foolish.

There are some challenges with the reliability and validity of this study as the sample is limited, as we include only one general studies group in English, 2 Spanish groups and 1 German group. There could also be differences between the Spanish groups and the German group that we do not find when we collapse these groups in the analysis. At a general level, Spanish differs from the other major foreign languages, German and French, in that it has the shortest tradition, the largest growth and the highest number of dropouts. This subject has also encountered some particular challenges related to lack of qualified teachers due to the great demand following its introduction in lower secondary school in 2002 (Christiansen, 2006; Carrai, 2014). It is also a challenge to compare vocational students with general studies 
students, as the latter group is more likely to be concerned with grades as they need good grades to be accepted into the university of their choice. Perhaps this is the reason why the foreign language students are more concerned with grades in their reflections than the English students, as the English groups are mainly groups attending vocational studies. Considering this, it is perhaps not surpising that the foreign language students are also more concerned with grammar, or correctness, and that they do not think that the five-step approach help them. They are perhaps more interested in the teachers' assessments than in their own learning process, so spending time on working with this method only felt like a waste of time. This may be the reason why these students responded that they did not become more motivated by the method.

Another issue is that the students filled in many forms as part of the intervention, and we can see from their responses that they were tired of this. Perhaps it is not the method itself some responded to negatively, but rather the way we designed the application of the method to collect research data. A final aspect that may have influenced the outcome negatively is that the teachers tried to use the target language, meaning English, German and Spanish, during the intervention, and this was perhaps too challenging for the students, especially for the foreign language students as they have had a rather short period of learning the language compared with the English students. The approach would perhaps have been more beneficial for the students if the mother tongue was used throughout. Still, quite many students here report that they have found the method useful, and some also feel more motivated. Hence, it is a method worth exploring in further studies, although adjustments may be necessary.

From the findings presented here, it seems like the approach suggested in this study, where students identify goals, success factors, obstacles, and make action plans, which they subsequently assess, provides a good tool for self-regulated learning. However, even though students may find the approach useful, they may not experience increased intrinsic motivation. To become intrinsically motivated, the psychological needs of feeling competence, relatedness and autonomy must be met (Ryan \& Deci, 2000), and these needs are not necessarily met by making a group of students apply a metacognitive learningstrategy. Perhaps the method should not be called a motivation method, but rather a method for raising consciousness and self-awareness, or perhaps a five-step approach for selfregulated learning. Whether students become motivated, depends perhaps on whether they set 


\section{Nordic Journal of Modern Language Methodology}

goals that they can reach, otherwise, they may not feel competent. For those who did not manage to follow up their plans, they may have felt neither competence nor autonomy. Still, providing the opportunity for students to reflect on and become conscious about how to proceed to reach goals and to deal with obstacles facilitates for self-regulated learning and consequently, increased motivation to learn (Ryan \& Deci, 2000).

\section{Conclusion}

This study has illustrated an approach that can be applied to support students in developing a metacognitive learning-strategy for learning languages. We call the approach the five-step motivation method. The five questions ask students to identify goals, success factors, obstacles, choose focus area, and decide on action within the focus area. Many of the students who participated in the study found this approach useful. Still, it seems like the approach needs some adjustment to facilitate increased intrinsic motivation. Perhaps the students need more support in thinking about what goals to set and what focus to choose, and perhaps the approach needs to be implemented more frequently and include more class discussions to ensure that all students feel relatedness. The next development in the approach will be to include the five questions central in this method regularly during the year, for example every month.

We have investigated the application of a metacognitive learning-strategy in language learning contexts in upper secondary schools in this study, but this approach could also be applied in all other educational contexts. Further research is needed on how this type of strategy could have been applied on other levels in the educational system, and in other subjects. It could also be interesting to see if applying the strategy in many subjects in the same group could have a different effect than just applying it in one subject, as we have done here. Another interesting aspect would be to link goals in school subjects to goals in life in general; how reaching goals in school subjects can be useful in relation to goals the students have in life in general. This is what we started out with in the project the current study is part of; a focus on setting objectives in life in general, and of school subjects. As integrating the two turned out to be a challenge in for example foreign language teaching, the current study only deals with applying the strategy in language subjects. 


\section{Nordic Journal of Modern Language Methodology}

\section{Acknowledgements:}

Thanks to the Norwegian Research Council, the Teacher Training Education at the University of Agder and the Directorate of Health for financial support to carry out the project.

\section{Literature}

Ames, C. (1992). Classrooms: Goals, structures, and student motivation. Journal of Educational Psychology, 84(3), 261-271.

Askland, S. (2018). “Too much grammar will kill you!” Teaching Spanish as a foreign language in Norway: What teachers say about grammar teaching. Nordic Journal of Modern Language Methodology, 6(2), 57-84.

Boekaerts, M., Pintrich, P. R., \& Zeidner, M. (2005). Handbook of Self-Regulation. Burlington: Elsevier Science.

Cardelús, E. (2015). Motivationer, attityder och moderna språk: En studie om elevers motivationsprocesser och attityder vid studier och lärande av moderna språk. (Doctoral thesis, The University of Stockholm). Hentet fra http://su.divaportal.org/smash/get/diva2:886009/FULLTEXT03.pdf

Carrai, D. (2014). Fremmedspråk på ungdomstrinnet: en analyse av motivasjon og andre faktorer involvert $i$ elevenes fagvalg og tilfredshet med faget. (Doctoral thesis, the University of Oslo).

Chang, L. Y.-H. (2010). Group processes and EFL learners' motivation: A study of group dynamics in EFL classrooms. TESOL Quarterly 44.1, 129-154.

Christiansen, A.(2006). Kunnskapsløftet og videreutdanning I spansk. Uniped 29 (3), 32-37.

Cohen, A. (2011). Strategies in Learning and Using a Second Language. Great Britain: Pearson.

Deci, E. L., Nezlek, J., Sheinman, L., \& Manis, M. (1981). Characteristics of the rewarder and intrinsic motivation of the rewardee. Journal of Personality and Social Psychology, 40(1), 1-10. doi:10.1037/0022-3514.40.1.1

Deci, E.L. \& Ryan, R. M. (1985). Intrinsic Motivation and Self-Determination in Human Behaviour. New York: Plenum Press.

Deci, E.L. \& Ryan, R. M. (2000). The 'what' and 'why' of goal pursuits: Human needs and the self-determination of behaviour. Psychological Inquiry. 11, 227-268. 


\section{Nordic Journal of Modern Language Methodology}

Dörnyei, Z. (2001). Motivational strategies in the language classroom. Cambridge:

Cambridge University Press.

Dörnyei, Z. (2007). Creating a motivating classroom environment. In J. Cummings \& C.

Davison (eds.), International handbook of English language teaching. New York: Springer US.

Flink, C., Boggiano, A. K., Barrett, M., \& Sherman, S. J. (1990). Controlling Teaching Strategies: Undermining Children's Self-Determination and Performance. Journal of Personality and Social Psychology, 59(5), 916-924. doi:10.1037/0022-3514.59.5.916

Graddol, D. (2006). English next (Vol. 62). London: The British Council.

Hellekjær, G. O. (2007). The Implementation of Undergraduate Level English Medium Programs in Norway: An Explorative Case Study. In R. Wilkinson \& V. Zegers (Eds.), Researching Content and Language Integration in Higher Education (pp. 68-81). Maastricht University Language Centre.

Hellekjær, G. O. (2010). Lecture comprehension in English-medium higher education. Hermes-Journal of Language and Communication Studies, 45, 11-34.

Jacobsen, D. I. (2005). Hvordan gjennomfфre unders $\phi k e l s e r$ ? Innføring $i$ samfunnsvitenskapelig metode. Kristiansand: Høyskoleforlaget.

Lamb, M. (2017). The Motivational Dimension of Language Teaching. 301-346. ISSN 02614448.

Langeland, G.M., Horverak, M.O. and Fagerhaug, J.P. (2018) Motivasjon - elevens eller lærerens ansvar? En case-studie om motivasjonsarbeid i en norskklasse i videregående skole. Norsklareren, 2, 36-41.

Koga, T. (2010). Dynamicity of motivation, anxiety and cooperativeness in a semester course. System 38.2, 172-184.

Kormos, J. \& Csizér, K. (2014). The Interaction of Motivation, Self-Regulatory Strategies, and Autonomous Learning Behavior in Different Learner Groups. TESOL quarterly, 48(2), 275-299. doi:10.1002/tesq.129

Ministry of Education and Research. (2013). English Subject Curriculum (ENG1-03). Oslo:

Norwegian Directorate for Education and Training. From https://www.udir.no/k106/ENG1-03

Ministry of Education and Research. (2013). Subject Curriculum for Foreign

Languages (FSP1-01) Oslo: Norwegian Directorate for Education and Training. From 


\section{Nordic Journal of Modern Language Methodology}

https://www.udir.no/k106/FSP1-01

Norwegian Directorate for Education and Training. (2017/2018). Skoleporten.

Elevundersøkelsen. Hentet fra

https://skoleporten.udir.no/rapportvisning/videregaaende-

skole/laeringsmiljoe/elevundersoekelsen/aust-agder-

fylke?enhetsid $=09 \&$ vurderingsomrade $=6 \&$ underomrade=48\&skoletype $=1 \&$ skoletype menu

NOU 2014:7. (2014) Elevenes laring i fremtidens skole. Oslo: Departementenes sikkerhetsog serviceorganisasjon Informasjonsforvaltning.

Ogre, M. \& Gjellan, M. (2017, 05.07.). Kraftig nedgang i skolefraværet. Nrk.no. Hentet fra https://www.nrk.no/norge/kraftig-nedgang-i-skolefravaeret-1.13589279

Postholm, M. B. (2007). Interaktiv aksjonsforskning: Forskere og praktikere i gjensidig bytteforhold. I M. B. Postholm (Red.) Forsk med! Laerere og forskere i laeringsarbeid. Oslo: Damm.

Reeve, J., Deci, E. L., \& Ryan, R. M. (2004). Self-determination theory: A dialectical framework for understanding socio-cultural influences on student motivation. Big theories revisited, 4, 31-60.

Reeve, J., \& Jang, H. (2006). What teachers say and do to support students' autonomy during a learning activity. Journal of educational psychology, 98(1), 209.

Rindal, U. (2012). Meaning in English, L2 attitudes, choices and pronunciation in Norway. (Doctoral dissertation) Faculty of Educational Sciences, University of Oslo, Oslo.

Rumberger, R. W. (2011). Dropping out : why students drop out of high school and what can be done about it. In. Ryan, R. M., \& Deci, E. L. (2000). Self-determination theory and the facilitation of intrinsic motivation, social development, and well-being. American psychologist, 55(1), 68.

Ryan, R. M. \& Deci, E. L. (2017) Self-determination theory: Basic psychological needs in motivation, development, and wellness. New York/London: The Guilford Press.

Ryan, R. M., Grolnick, W. S., \& Sarason, I. G. (1986). Origins and Pawns in the Classroom: Self-Report and Projective Assessments of Individual Differences in Children's Perceptions. Journal of Personality and Social Psychology, 50(3), 550-558. doi:10.1037/0022-3514.50.3.55 


\section{Nordic Journal of Modern Language Methodology}

Sansone, C. \& Harackiewicz, J. (2000). Intrinsic and Extrinsic Motivation. New York: Academic Press.

Schunk, D. H. \& Zimmerman, B. J. (2012). Motivation and self-regulated learning: Theory, research and applications. New York/London: Routledge.

Skaalvik, E. M. \& Skaalvik, S. (2017). Skolen som laringsarena: Selvoppfatning, motivasjon og laering (2. ed.). Oslo: Universitetsforlaget.

Stipek, D. J. (2006). Motivation and instruction. In Alexander, P. A. \& Winne, P-. H. (eds.) Handbook of educational psychology (2nd ed.). Mahway, N. J.: Erlbaum.

Ushioda, E. (2008). Motivation and the good language learners. In Griffiths, C. (ed.) Lessons from Good Language Learners. Cambridge: Cambridge University Press.

Zimmerman, B., \& Schunk, D. (1989). Springer series in cognitive development. Selfregulated learning and academic achievement: Theory, research, and practice. Springer Verlag Publishing. 